\title{
NUMBER CATEGORY AND (THE) MEANS OF ITS ACTUALIZATION IN THE SPHERE OF NOUNS
}

\section{Mizetska V. Y., Zubov M. I.}

\section{INTRODUCTION}

The paper deals with the notion of number and the ways of its actualization in different languages of the world.

This problem was considered in a number of articles and monographs (see the reference part of the given work) but it is time to generalize separate observations and classify the means of the number formations in the sphere of nouns.

More than 30 languages were analyzed in the process of the research. The data compiled by the other scholars were also used (see the part References).

The methods of immediate observation, comparison, componential analysis were widely applied in the process of investigation. Objectivity of the conclusions is based on the volume of the languages taken for the research and is supported by many facts compiled by the other scholars.

\section{The category of the number in the sphere of the noun}

The analysis of some languages puts under doubt the opinion of scholars that the singular is primary while the plural forms are derivative ones. For example, the word oran in the Malay language does not have an exact status of the singular or of the plural. Moreover, it rather corresponds to our plural than the singular as it is necessary to add the word which denotes 'one' to form the singular of the lexeme 'oran' and some other words.

The same phenomenon is observed in many Altaic languages where one and the same grammatically non-specified word can be used to denote the plural or the singular. That is why in these languages one and the same appellative can denote, on the one hand, an individual person and, on the other hand, - an uncertain number of persons.

E. Cassirer believes that differentiation of the number relations goes back to the human body and its parts.

The body is the primary model of the initial primitive calculations. All the notions of the number before they became verbal notions are purely mimic gestures.

The research of many languages of the world shows that there exist such types of the number as the singular, dual, trial, plural limited (narrow) and the 
plural unlimited (wide) in the sphere of nouns. The dual and trial numbers alongside the singular and plural can be found in the Papuan languages.

In ancient Indo-European languages (Sanskrit, ancient Greek), in Ancient Germanic languages including the ancient English, the category of the number was presented by three types of the number: singular, dual and plural.

Dual number died out in almost all modern Indo-European languages. One of the rare languages which 'preserved' the dual is the Slovenian language. The dual number is registered in the classic (al) Arabic, in the Koryak languages, but is lost in its cognate language - the Chukchi (Chukchee) language.

The dual is used in the Hebrew language. Alongside the plural there are special forms for the pair words:

mishkafaim ( spectacles); misparaim (scissors), nehiraim (nostrils), etc.

In all these cases the special ending -aim is used while in the plural the forms with the -ot ( for the feminine gender (normot (nouns)) and the -im for the masculine gender (Klalim (rules)) are used.

As we see, the main semantic sphere which provides the dual forms is the sphere of the pair (dual) objects and the objects situated on both sides of the symmetry axis, which is typical of the anatomy of the human being and many species of animals (eyes, hands, boots, etc.). But in the English language the dual number is not used even in the cases of duality. Its functions are fulfilled by the classic (traditional) plurals: trousers, tongs, etc.).

In the Chinese languages the category of the plurality and the number in general is not used for the nouns. The word $g \bar{o} u$ depending on the context may mean 'dog' or 'dogs'. The grammatical formants (special morphemes) are not used. The plurality here is actualized with the help of different semantic means - numerals and the words denoting volumes, sizes, etc.

For the exact number indication in the overwhelming majority of languages there are used numerals. In all the languages where there is a corresponding numeral 'one' it agrees with the nouns in the singular: one nut, one ship, etc. All the rest numerals require the use of the nouns in the plural if these languages are based on the principle of inflexion: two nuts, two houses, etc.

But for the isolating languages this principle is not suitable. Here works another system of calculation (counting). There are special count-nouns (countwords). They are added to the word combinations having the numerals:

sān bèi chá (3 cups of tea). The noun bèi remains unchangeable. The nouns do not agree with the numerals as it occurs in the inflexional languages.

One of the most common count-words is the word gè: e.g. sì gè rén (4 persons). The count-noun gè as well as the basic noun-determinatum 'rén' remains unchangeable.

The other count-words are:

wèi - used with the individuals with whom you want to be polite; 
jiàn - for rooms;

pìng - for bottles.

The words suì (year when the age is fixed), word:

nián (year) and tiān (day) unite the functions of the noun and count-

shí suì (ten years), liù nián (six years), wŭ tiān (five days).

The word Hào is also a count-word which has the meaning 'number':

sān hào fáng (jiānn) denotes 'room number 3'.

The count-words are also used when the nouns combine with the words 'This, that, which':

Nèi gè rén ? (Which person\man?)

The count-word for the bus ticket and other objects with smooth surface is the word zhăng, but when it deals with two bus tickets the Chinese people use the word combination liăng gè as it suggests the number of the passengers and not the number of tickets.

The count-word dù denotes 'degree, grade' and is used when it concerns the temperature or angles, for example, sānshiwŭ dù (35 degrees, centigrade).

For the sizes the count-word hào is aslo used: xiă hào (small size); zhōng hào (middle size); dà hào (big size), tè dà hào (very big size).

The count-noun $x i \bar{e}$ may be used with any nouns no matter which countword they usually take. Comp.: liăng tiá lù or liăng xiē lù (two roads).

$X i \bar{e}$ is also a count-word for the uncountable nouns, such as water (shū), which do not have their special count-words typical of the countable nouns: nèi xiè niùnăi (that milk).

The lexeme xie (yixiē) also may be used in the meaning 'several', 'some': yixiē rén (several persons).

The same holds true for the other isolating languages. Such phenomenon can be called the zero inflexion.

In some languages the use of the plural forms is limited. Fr. Boas said that in the language Kwakiutl the idea of plurality is not developed. The reduplication of the names rather denote the objects in different places or different kinds of the same objects than the plurality itself. It is the so-called distributive number which differs from the traditional one:

"The idea of plurality is clearly developed. Reduplication of a noun expresses rather the occurrence of an object here or there, or of the different kinds of a particular object than plurality. It is therefore rather a distributive than a true plural. It seems that this form is gradually assuming a purely plural significance" ${ }^{1}$.

${ }^{1}$ Boas Fr. Handbook, I, p. 444. Цит. По: Кассирер Э. Философия символических форм. T. 1. Язык. М.: Академический проект, 2011, с. 206. 
There are some languages where only certain words (the minority of words) have the form of the plural. One of the languages is Hupa. These lexemes, as a rule, denote the age, special status or the family relations.

In the Aleut languages there are two ways of plurality expression. Some plural forms are used for the objects; the other plural inanimate forms are applied to the inanimate objects. We suggest naming such plurality the objective plurality.

In the Altaic languages one and the same grammatically not specified word may be used for the expression of the singular and plural.

In the English language there are nouns, which having the form of the singular, may fulfil the functions both of the singular and of the plural: sheep, deer, grouse. They are qualified as Singularia Tantum nouns. It means that they agree both with the verbs in the singular form and in the plural one without any changes in their graphical images.

In three languages - Ukrainian, Russian and English - there are cases when the noun has only one form of number: only the singular (Singularia Tantum) or only the plural (Pluralia Tantum). For example, only the plural form in the Ukrainian language have the words граблі (the rake); дрова (the wood) etc., in the Russian language - дрожжи (yeast), ножны (scabbard or sheath), etc.

In the German language the status of Pluralia Tanum have the words Eltern, Geschwister, Zwillinger, etc.

In the English language these are mostly the pair (twin) objects designations - scissors, spectacles, tongs and some other lexemes, for example, clothes.

We believe that it is possible to single out also the cases which we suggest calling the quasi-plural. In their form, these words coincide with the noun of the plural but agree with the verbs in the singular: e.g. the news is good; mathematics is not easy, etc.

The existence of the quasi-plural forms is explained by the fact that these words can be perceived not as discrete sets but as the collective units, which require the use of the singular form of the corresponding verb.

E.Cassirer gives an example from the Indo-European languages which supports this point of view. In Sanskrit and Greek the plural nouns of the neuter gender agree with the verb in the singular. It is explained by the fact that in the past the ending $-e$ of the nouns of the neuter gender did not have the meaning of the plural but derived from the ending $-a$ typical of the feminine gender which was the indicator of the collective abstract nouns. Thus, the forms with the ending $-a$ were formerly not the form of the singular but the forms of the collective nouns which grammatically could be treated in different ways.

There are also the nouns, which do not have the form of plural - the socalled Singularia Tantum nouns. In the Ukrainian language they are: нежить 
(a cold in the head, a running nose), nixoma (infantry), zopox (peas), etc. In the Russian language here belong the words старость (old age, oldness), сено (hay), медь (сорper), соль (salt), etc. In the English language the words money, sugar, friendship also have only the form of the singular. Some of them agree only with the verbs in the singular: e.g. 1. The money is lost. 2. Sugar is sweet.

The other lexical units are ambivalent and can fulfil both functions of the singular or the plural depending on their semantics. The word people agrees with the verb in the plural when it means 'human beings': e.g. The people were dispersed by police.

When this word is used in the meaning 'nation' it agrees with the verb in the singular: e.g. The Ukrainian people is invincible.

But when different nations are suggested then this lexeme may be used in the plural: The peoples of the world are against war.

The status of Singularia Tantum in the German language have the words das Geflügel, das Wild, das Obst, etc.

Ambivalent in the English language are some nouns, which denote animals and birds: deer, grouse, sheep, swine, etc. Depending on the context, they agree with the verbs in the singular or plural: e.g. 1. The sheep are on the meadow. 2. Every sheep was sheared (shorn) in summer.

In some languages of the world one can find the contact and distant forms of the plural: the first ones are used to denote the objects, concentrated in one place and/or functioning as the one whole /integral unit (fingers, sails, etc.).

The second ones are used for denoting the objects which are situated in different places and which are not functionally connected.

The morphological expression of the contact and distant forms of the plurality of nouns can be found in some Dagestan languages, South-Aztec languages and others. For example, in the Budukhsh language

(1) t'il.iber denotes 'fingers on one hand';

while

t'il.imber denotes 'fingers on two or many hands', that is of one person or different persons;

(2) čärx.iber denotes 'the wheel of one car', while čärx.imber - 'wheels in general or wheels of different cars'.

The languages having the category of the dual plurality are constantly being reduced. In the Semitic proto-language it existed but in some derivative languages it disappeared.

In the Greek language the dual number in some dialects died out (was eliminated) in the prehistoric period. In the texts of Homer these forms have the character of relict.

Only in the Attica(n) dialect the dual number was actualized for a longer period of time, but it gradually faded out in the IV c.b.c. 
The relicts of the dual number can be found in some German dialects; for example, Bavarian and Westphalian.

In the Ancient Egypt the dual number was widely used while in the Coptic language it remained in the status of relict ${ }^{2}$.

There are also languages with the trial number. The trial number of nouns, as well as the dual number, can be found in the Malaya-Polinesian languages.

The languages of the Australian aborigines are also known for their dual and trial forms.

Besides the dual and trial number, many languages differentiate between two kinds of the plural: the narrower plural for two or several objects and the wide plural for many objects. This phenomenon fixed by Dobritzhoffer ${ }^{3}$, can be found in the Semitic languages, for example, in the Arabic. Alongside the dual, there is the limited plural, which suggests 3-9 objects and the wide plurality for 10 objects and more. This latter form also denotes the uncertain number of objects.

This triad of the number which looks like (1) object - (2) several objects and (3) a great number of objects, can be found also in some Cushitic languages.

W. fon Humboldt believed that the meanings of plurality and singularity were formed from the general collective meaning of words. The plurality was understood just as a heap, mass. It was not yet the notion of division. The notion 'number' grows from this amorphous notion of the mass.

In some languages the plurality is often clearly expected only in terms of the animate objects but is not actualized when the inanimate objects are dealt with. In the Yakut language the parts of the body as well as clothes have the form of the singular even if one person has two or more articles of the garments but they acquire the form of the plural if they belong to several persons.

On the basis of these and other data one can draw a conclusion that the grammatical number category is stipulated rather by the number of persons than only by the number of objects the individuals have.

\section{Classification of the noun number formation means}

Category of the noun number is not universal. This category is not actualized in such languages as the Sino-Tibetian languages, including the Chinese language. It is not actualized in the languages of New Guinea and Australia, in the languages of some Amazonian tribes (piraha(n)).

2 See in detail: Кассирер Э. Философия символических форм. Т. 1.Язык. М.: Академический проект, 2011.

${ }^{3}$ Dobritzhoffer. Historia de Abiponilus, II, p. 166. 
In the languages where this category is actualized different means of its representation are used:

- Reduplication, that is the repetition of the whole words or their parts. For example, in the Malay language the word rumah denotes a 'house'. The plural here is formed with the help of repetition, that is reduplication of this word: rumah (house) - rumah (houses).

In the Indonesian language orang denotes a person, while orang-orang means people; buah means fruit, while buah-buatan denotes a lot of fruits.

- Changes of the tone. This form of plural actualization can be found in the language called Shilluck. In this language, the word jit, which is pronounced with the high tone denotes 'ear'. The plural is formed due to the change of the tone that switches from the high to the low one: jit $\downarrow \rightarrow$ jit $\uparrow$ (ear $\rightarrow$ ears).

- Suppletion. This form of plurality suggests the formation of the plural forms of the nouns from the words having another root, different from the root of the basic word in the singular. Suppletion can be found in different languages but it is not a widely spread way of the noun number formation. Rare examples can be found in Russian: человек (person) $\rightarrow$ люди (people, persons) and French: oeil $\rightarrow$ yeux.

- Transfixation. Transfixation is typical of the Semitic languages. Transfixes are a combination of vowels which pierce the root of the word made up of the consonants: e.g.

Arabic

1) hamir $\rightarrow$ himar (donkey $\rightarrow$ donkeys)

2) harb $\rightarrow$ hurub (war $\rightarrow$ wars).

Transfixes should not be confused with the internal inflexion as it used to be in the past. The first typologies did not differentiate between internal inflexions and transfixes. Only later, such scholars as Skalichka and Sapir realized that these phenomena are not identical. In case of internal inflexion the vowels are (the) part of the root, forming it with the consonants. The vowels in the Semitic languages are not elements of the root. The latter are represented only by the consonants. These vowels form the affix which is called a transfix.

In the words foot $\rightarrow$ feet the alterated vowels are part and parcel of the root, while the sound changes $a-i \rightarrow i-a$ in the Arabic word hamir hamir $\rightarrow$ himar) are not formants of the root. It made the scholars single out transfixes and separate transfixional languages from the inflexional languages in their typological schemes (Sapir, Skalichka).

V.A. Plungian does not rigorously differentiate between transfixation and internal inflexion, using these terms alternatively ${ }^{4}$.

\footnotetext{
${ }^{4}$ Плунгян В.А. Общая морфология. М.: Эдиториал УРСС, 2000, с. 93.
} 
Transfixes fulfil many grammatical and semantic functions in the Semitic languages but one of them is the expression of the plural: e.g. daxlum $\rightarrow$ daxulin. It is the so-called "broken plurality". But it does not embrace/cover all nouns. There are about 30 models of the broken plurality in the Arabic language.

J.P. Kurilovich and V. Plungian believe that in ancient times the Semitic vowels were components of the root and only gradually these vowels functionally separated from the consonants.

At the same time V. Plungian admits that status of the vowels in the Arabic words remains debatable.

The idea of the special vowels status as transfixes (diffixes) is supported by V. Starinin, I.A. Melchuk, J.McCastle, J. Goldsmith ${ }^{5}$ and others. A. Belova suggests the compromised interpretation of the Semitic root: she includes into the Arabic root the constant consonants and alternative vowels.

We support the "consonant" interpretation of the root in the Semitic languages and believe that the vowels are pure transfixes. They are grammatical or semantic indicators specifying the meaning of the root.

- Combination of transfixation and inflexion (endings) is observed in the Semitic languages, including the Hebrew: e.g.

eled (child) $\rightarrow$ yieladim (children);

rakevet (train) $\rightarrow$ rakavat (trains).

- Inflexion. The use of different endings (inflexions) is one of the most frequently used ways of the plural formation. It is one of the main characteristics of the inflected languages - Ukrainian, Russian, German, English, etc. Inflexions are used also in the Semitic languages, for example, in the Hebrew.

The plural forms of the nouns belonging to the feminine gender are built due to the addition of the ending -ot :

nahash (snake) $\rightarrow$ nahashot (snakes),

while the nouns belonging to the masculine gender are built due to the addition of the ening -im :

mivrack (telegram) $\rightarrow$ mivrakhim (telegrams).

In modern Ukrainian, Russian and English languages the form of two numbers - singular and plural are actualized.

In contrast to the Ukrainian and the Russian languages, the idea of singularity in the English language is expressed only by the zero morpheme.

The semes of singularity in the Ukrainian and the Russian languages are expressed be special morphemes, for example, -a (nтиц $a$ - bird) and zero morphemes (sip - sight), etc.

\footnotetext{
${ }^{5}$ See in details: Указ. Соч., с. 94.
} 
The category of the plural in all these languages is represented by the special formants of plurality.

In the English language these special morphemes are $-s$ and $-e s$. As to the borrowings the endings of the donor-languages are sometimes preserved/remain. For example, the words borrowed from the Greek language phenomenon, criterion take the ending $-a$. The Greek borrowings analysis, basis, crisis, hypothesis, thesis, etc. in the plural change the ending -is and acquire the ending -es: analyses, bases, crises, hypotheses, themes, etc.

The ending -um in the Latin borrowings is replaced by the plural ending -a: agendum - agenda, datum - data, etc.

But now there is a strong trend to assimilation of the borrowed words in terms of the plurality formants. That is why some borrowings have two variants of the plural formation:

1) with the ending characteristic of the English language;

2) with the ending of the language-donor: e.g. the nouns borrowed from the French which are not completely assimilated and have two forms of the plural:

bureaux $\rightarrow$ bureaux and bureaus;

plateau $\rightarrow$ plateaux and plateaus;

though they coincide in their pronunciation in the plural [z].

Some Latin borrowings, such as formula, focus, stratum, etc., through the process of assimilation have developed parallel native forms:

formula $\rightarrow$ formulae and formulas;

focus $\rightarrow$ foci and focuses;

stratum $\rightarrow$ strata and stratums; etc.

But at the same time many borrowings are fully assimilated and now have the only ending typical of the pure English words: e.g.

Greek: electron $\rightarrow$ electrons;

Lat.: diploma $\rightarrow$ diplomas; etc.

It should be noted that foreign plural forms are more bookish than the native ones.

There are also double plurals used with difference of meanings:

genius

1) geniuses ( men of genius)

2) genii (spirits)

index

1) indexes (tables of contents)

2) indices (in mathematics) etc.

- Internal inflexion (internal modification; grammatical alteration). This means of the plurality actualization is widely spread in the English and German languages: e.g. 
Engl.: foot $\rightarrow$ feet; goose $\rightarrow$ geese; tooth $\rightarrow$ teeth;

Germ.: Ofen $\rightarrow$ Öfen.

In Germanic languages it is a common thing to single out:

1) Ablaut - the historical alteration of the vowels in the root:

Engl.: foot $\rightarrow$ feet;

2) Umlaut, or metaphony, that is the changes of the vowels of the root, their shift to the fore under the influence of the vowels of the suffix or the ending (inflexion) : e.g.

Germ.: Vater $\rightarrow$ Väter; Mutter $\rightarrow$ Mütter.

- Combination of internal inflexion and final inflexion (endings).

It is typical of the German language: e.g.

Gast $\rightarrow$ Gäste.

In the English language the unique case of such combinatory use of internal inflexion and endings is the word children from the singular child. Here the sound [i] transforms into the diphthong and at the same time the atavistic ending - en is added to the singular form.

- Prefixation. Prefixation as the means of the plural formation in nouns is practiced rarely. Sapir gives an example from the language Nass (British Columbia), where the word an'on denotes $a$ hand. The plural form is based on the addition of the prefix $-k a$ to the singular form:

an'on $\rightarrow$ kaa'on,

which correspondingly means 'hands'.

In the Bantu languages such pair objects, as eyes and ears, shoulders and breasts, knees and feet form a special class which is actualized by special prefixes.

Alongside the natural pairs occur the artificial ones. Scholars noticed the pairness of some instruments (tongs, scissors, etc.).

- Suffixation. The use of the concrete monosemantic suffixes of the plural is characteristic of the agglutinative languages. The suffix -lar/ler in the Turkish languages has only one grammatical meaning that of the plural:

ev (house) $\rightarrow$ evler (houses);

dal (branch) $\rightarrow$ dallar (branches).

The choice of the vowel in the suffix is defined by the law of the vowel harmony. It means that the root vowel stipulates the choice of the vowel in the suffix. If in the root there is the vowel $-a$, then the suffix -lar with the same vowel will be added:

Turk.: masa $\rightarrow$ masalar. added:

If in the root there are the vowels $-e,-i$, then the suffix -ler will be

defter $\rightarrow$ defterler;

dis $\rightarrow$ disler. 
Assimilation of the suffixes is possible only in rare cases. The Tartar word kazan in the plural has the suffix -nar instead of -lar due to the progressive assimilation: the root consonant $-n$ stipulates the transformation of the $-l$ into $-n$.

The changes of the vowels in the root are encountered rarely: e.g. in the Bashkir language the singular of the word 'house' is -at while in the plural it is transformed into the etler (instead of the atler). The root vowel here is distantly assimilated under the influence of the suffixal vowel $-e$.

Articles in some languages are used for the differentiation in the sphere of the noun number. For example, in the French language many nouns in the singular and plural are pronounced in one and the same way though their graphical images differ. Only the article in this case is the indicator of the number:

le paysan $\rightarrow$ les paysans;

la chat $\rightarrow$ les chats.

Such cases can be found in the German language:

der Arbeiter $\rightarrow$ die Arbeiter;

das Fenster $\rightarrow$ die Fenster.

The function of the number marker can be performed by the zero article. In the English language zero article may show that the noun is used in the plural when the word itself remains unchangeable:

a sheep $\rightarrow$ sheep;

a swine $\rightarrow$ swine;

a deer $\rightarrow$ deer; etc.

There are special cases when the designation of the number of objects merges with the designation of the object itself. One and the same naming unit simultaneously shows the number of objects and is the designation of the object(s) themselves.

In the language of the Fiji they use special words which denote the groups of coconuts consisting of two, ten, a hundred and a thousand of pieces. E.Cassirer came to the conclusion that such an indiscrete combination of the quantity and objects was a typical phenomenon of many ancient languages.

In the Malayo-Polynesian languages the numerals are combined with the nouns not directly but they add some determinatives to the noun. For example, 'five houses' sounds as 'houses, five tails', the word combination denoting 'four stones' sounds as 'stones, four circular pieces', etc. 


\section{CONCLUSIONS}

As a result of the research we classified all the means of the noun plural forms into the following groups: 1) internal inflexion; 2) final inflexion (endings); 3) prefixation; 4) suffixation; 5) suppletion; 6) transfixation; 7) changes of the tone; 8) articles.

The in-depth analysis showed that the above - mentioned ways of the plural formation are combined in some languages: transfixation and final inflexion (Hebrew); internal inflexion and final inflexion (German).

There are still debatable questions. Some scholars do not differ transfixes and internal inflexion (the alteration of vowels in the root) while the other scholars insist on their principal difference. We support the latter point of view as the vowels forming the transfix are not part and parcel of the root while the internal inflexion is the alteration of vowels which are components of the root.

The dual, trial and limited plural forms are rarely used in the world languages. The dichotomy of the singular and plural lies in the basic model of the number category actualization. At the same time Singularia Tantum and Pluralia Tantum forms are typical of some languages including the English language and the Ukrainian language.

Some transformations which violate the traditional number references are explained by the stylistic causes and are connected with the expressive effects of the utterances.

\section{SUMMARY}

The paper is devoted to the analysis and classification of the different means of the noun plural forms actualization.

Such analysis was carried out on the basis of about 30 languages belonging to different families and types: English, German, Russian. Ukrainian, Turkish, Chinese, Hebrew and other languages were taken for observation.

Analysis shows that the dichotomy of the singular and the plural lies in the basic model of the number category actualization. The dual, trial and limited plural forms are rarely used in the world languages. Quasisingular and quasiplural forms and ambivalent number forms of the nouns are also used in some languages including the English, Russian and Ukrainian languages.

All the noun plural forms were classified in the following groups: 1) internal inflexion; 2) final inflexion (endings); 3) prefixation; 4) suffixation; 5) suppletion; 6) transfixation; 7) changes of the tone; 8) articles.

There are also hybrid plural formation models when transfixation is combined with final inflexion (Hebrew), internal inflexion is combined with final inflexion (German).

The correlation of the terms 'transfix' and 'internal inflexion' is still debatable. Some scholars believe that they are identical while the author of the 
paper supports the idea of their difference. The internal inflexion suggests that vowels are components of the root while any transfix is formed by the vowels which are not part of the root which consists only of the consonants (The Semitic languages).

Some transformations which violate the traditional number references are explained by the stylistic causes.

\section{REFERENCES}

1. Белова А.Г. Морфемы в семитских языках (на материале арабского). Морфемы и проблемы типологии. - М.: Наука, 1991. C. 177-219.

2. Булатова Л.Н. Еще о грамматическом статусе категорий числа существительных в русском языке. Проблемы структурной лингвистики М : Наука, 1983. С. 120-130.

3. Виноградов В.А. Основы африканского языкознания. - М.: Аспект-пресс, 1997.

4. Гранде Б. М. Введение в сравнительное изучение семитских языков. М.: Наука, 1972.

5. Гузев В.Г., Насилов Д.М. К интерпретации категорий числа имен существительных в тюркских языках. Вопросы языкознания. 1975. № 3. C. $98-111$.

6. Зализняк А.А. О показателях множественного числа в русском склонении // To honor Roman Jacobson: Essays on the occasion of his $70^{\text {th }}$ birthday. The Hague: Mouton, 1967. P. 2328-2332. 1988.

7. Касевич В.Б. Семантика. Синтаксис. Морфология. М.: Наука,

8. Кассирер Э. Философия символических форм. Т 1: Язык. М.: Академический проспект, 2011.271 с.

9. Кибрик А.Е. Числовые формы несчетных существительных в дагестанских языках. Очерки по общим и прикладным вопросам языкознания. М.: МГУ, 1992. С. 131-135.

10. Кубрякова Е.С. Основы морфологического анализа (на материале германских языков). - М.: Наука, 1974.

11. Мельчук И.А. О «внутренней флексии» в индоевропейских и семитских языках. Вопросы языкознания. 1963. № 4. С. 27-40.

12. Меновщиков Г.А. Способы выражения единственного и множественного числа в языках разного типа. Вопросы языкознания. 1970. № 1. C. 82-88.

13. Плунгян В.А. Общая морфология. Введение в проблематику. М.: Эдиториал УРСС, 2000. 384 с. 
14. Поливанова А.К. Выбор числовых форм существительных в русском языке. Проблемы структурной лингвистики. М.: Наука, 1983. C. $130-145$.

15. Ревзин И.И. Так называемое «немаркированное множественное число» в современном русском языке. Вопросы языкознания. 1969. № 3. C. 102-109.

16. Смирнова И.А. Категория числа в языках с немаркированным именем (на материале иранских языков). Вопросы языкознания. 1981. № 2. C. $77-87$.

17. Dixon R.M. Noun Classes. Lingua. 1968. № 1. P. 104-125.

18. Kurylowichz J. The Inflectional Categories of Indo-European. Heidelberg, 1964.

19. Plank F. Paradigms: the Economy of Inflexion. B.: Mdg, 1991.

20. Rayevska N.M. Modern English Grammar. Kiev. 1976.

21. Wurzel W.U. Flexions: Morphologic und Natürlichkeit. B.: Academic-Verlag, 1984.

\section{Information about the authors:} Mizetska V. Y., Doctor of Philology Sciences, Professor, Head of the Foreign Languages Department, International Humanitarian University 33, Fountain str., Odessa, 65009, Ukraine

Zubov M. I., Doctor of Philology Sciences, Professor at the Department of Germanic and Oriental Languages, International Humanitarian University 33, Fountain str., Odessa, 65009, Ukraine 